Соколюк С.М., кандидат історичних наук, доцент, доцент кафедри Військово-Морських Сил НУО Украйни імені Івана Черняховського (м. Küв)

\title{
СТВОРЕННЯ ДВИГУНІВ ПІДВОДНИХ ЧОВНІВ НА ВІТЧИЗНЯНИХ ТЕРЕНАХ (ДРУГА ПОЛОВИНА ХІХ - ПОЧАТОК ХХ СТ.)
}

У статті розкрито процес розвитку конструкторських рішень щзодо створення двигунів для підводних човнів у другій половині XIX - початку ХХ сm. Відображено діяльність вітчизняних винахідників щуодо вирішення проблеми розвитку двигунів, щуо мали б забезпечувати рух підводного човна як особливого класу бойових кораблів у надводному та підводному положенні. Розпочавщи з педального та ручного приводу для руху субмарини, конструктори всебічно удосконалювали двигуни, створюючи та встановлюючи на човни бензинові та гасові мотори, електромотори та дизельні двигуни, щзо забезпечували збільшення радіусу дї̈ човнів.

Ключові слова: підводний човен, двигун, рушій, парова машина, бензиновий мотор, гасовий мотор, дизельний двигун, електромотор.

В умовах відродження Військово-Морських Сил Збройних Сил України особливого значення набуває вивчення досвіду будівництва i розвитку родів флоту, зокрема підводних сил, оскільки саме підводні човни, поряд із мінною зброєю, мають стати асиметричною відповіддю агресивним устремлінням Російської Федерації, ймовірність вторгнення якої 3 моря залишається надзвичайно високою. Отже, у контексті відродження підводних сил ВМС 3С України бачиться актуальним розглянути досвід створення двигунів підводних човнів та їх рушіїв у 1850 рр. XIX ст. - 1905 р.

Окремі аспекти цієї теми висвітлювали Г. Трусов, О. Тарас, С. Шер та інші. Однак комплексного дослідження питання генези розроблення та 
використання на субмаринах двигунів i рушіїв заслуговує на окреме вивчення, чому й присвячена подана публікація.

Отже, метою дослідження визначено аналіз досвіду створення двигунів для нового роду сил флоту - підводних човнів - на вітчизняних теренах у другій половині XIX - початку XX століть.

Варто зазначити, що в основі підводного кораблебудування, як i розвитку підводної справи у другій половині XIX - початку XX ст., постала проблема розвитку двигунів, що мали б забезпечувати рух підводного човна (далі - ПЧ) як особливого класу бойових кораблів у надводному та підводному положенні. Якщо швидкий розвиток металургії у XIX столітті забезпечив виробництво прокатного металу різних сортів та якості і дав змогу порівняно легко вирішити питання обрання міцного матеріалу для будівництва корпусів субмарин, то набагато складніше було створити для них відповідні двигуни [17, с. 53]. Це зумовлено складністю використання двигуна для підводного човна, що завжди має бути готовий до занурення, причому двигун має працювати без сполучення з атмосферою і не виділяти шкідливих газів [14, с. 99]. Невеликі розміри корпуса човна не давали змоги встановити на ньому єдиний на той час механічний двигун - парову машину, що потребувала не тільки пального та води, а й значну кількість допоміжних механізмів, які мали низький ККД і значні розміри [9, с. 139]. Активне вирішення цієї проблеми на шляху розвитку підводної справи на вітчизняних теренах припадає на період до завершення російсько-японської війни 19041905 pp.

Базою для подальших розробок цього виду зброї у Росії першої половини XIX ст. стали проєкти підводних човнів К. Черновського (1829 р.), О. Подолецького (1831 р.), К. Шільдера (1834 р.) [14, с. 25], хоча вони й мали недоліки своїх попередників, зокрема використання м'язової сили в якості двигуна, що не давало змоги вирішити проблему. Вже у другій половині XIX ст. російські конструктори М. Спірідонов, О.Герн та 
I. Александровський здійснили перші спроби використати машину для руху підводного човна [10, с. 35].

Так, у жовтні 1855 р. російський механік, офіцер флоту М. Спірідонов надав до Морського Технічного Комітету (далі - МТК) проєкт підводного човна, що мав би рухатися за допомогою гвинта від повітряних машин, на які подавалося б стиснуте повітря зі сталевих балонів, при цьому відпрацьоване повітря мало відводитися у човен для забезпечення дихання екіпажу, а залишок - за борт $[14$, с. 43$]$. Утім, через недосконалість проєкт відхилили [3, c. 285].

Велику зацікавленість у російського уряду викликали пропозиції побудувати підводний човен баварця Вільгельма Бауера (1822-1875рр.), оскільки через невдачі у Кримській (Східній) війні (1853-1855рр.) та технічну відсталість російського флоту підводний човен міг бути використаний проти флоту союзників [14, с. 45]. Після першого невдалого проєкту човна, в якому була використана м'язова сила для руху, що робило його безперспективним [14, c. 48], В. Бауер запропонував побудувати “підводний корвет”, озброєний чотирма гарматами й оснащений двома двигунами: для надводного положення - паровою машиною, а під водою пневматичним двигуном на стисненому повітрі [13, с. 65]. Проте через втрату підтримки Морського Технічного Комітету контракт про співпрацю 3 ним було розірвано [13, с. $65 ; 14$, с. 49$]$.

Проблему руху під водою за допомогою механічної сили у своїх дослідах сподівався вирішити військовий інженер штабс-капітан (у майбутньому полковник, а згодом генерал-майор інженерної служби) Отомар Герн (1827-1882 pp.) [10, с. 36]. На човні, збудованому у 1863 р. на Іжорському заводі у Санкт-Петербурзі, він спробував використати газовий двигун, що мав працювати на зрідженому аміаку, сконструйований військовим хіміком, полковником М. Петрашевським [13, с. 70]. Проте його недосконалість і небезпека для екіпажу змусили відмовитися від цієї ідеї та повернутися до м’язового приводу гвинта, що вело проєкт у глухий кут. 
Утім, набутий власний та іноземний досвід дав змогу винахіднику спроєктувати новий підводний човен 3 енергетичною установкою, що складалася 3 парового котла і парової двоциліндрової машини потужністю 6 к.с. для обертання гребного гвинта $[13$, с. 97; 17, с. 55]. У надводному положенні для руху в котлі спалювалося вугілля, у підводному - скипидар, що розпилювався за допомогою форсунки, сконструйованої відомим російським інженером-теплотехніком О. Шпаковським; горіння забезпечувалося стиснутим повітрям із балонів, якого за розрахунками мало вистачити на 5 годин підводного плавання.

Прагнучи удосконалити спосіб руху свого човна у підводному положенні, О. Герн запропонував спалювати в топках інше хімічне паливо (т.зв. “ракетну суміш”), що не вимагало у процесі горіння атмосферного повітря, оскільки до його складу входив кисень. Він передбачив також резервну можливість переведення парової машини на роботу замість пари стиснутим повітрям із запасних резервуарів у режимі пневматичного двигуна [13, с. 98; 17, с. 56-57]. Після завершення будівництва 1864-1867 рр. на Олександрівському ливарно-механічному заводі [13, с. 97; 17, с. 56] та проведення випробувань комісія Військового міністерства констатувала, що “горіння пального відбувається за рахунок власного кисню і що воно йде досить рівномірно, принаймні не створює спалахів, які можуть пошкодити топку або котел” [16, арк. 11-12].

Кількарічні випробування підтвердили можливість створення такого двигуна і у серпні 1871 р. воно отримало схвалення членів МТК [17, с. 5758]. Таким чином, досліди винахідника практично довели можливість створення єдиного двигуна, але технічні складнощі, пов'язані 3 неможливістю надійно герметизувати топку котла, переведенням його на різні види палива, а також необхідність мати їх значні запаси і потреба у великій кількості стисненого повітря унеможливили створення субмарини.

Маючи певний запас часу, винахідник планував використати його для установки на човні електродвигуна i y 1876 р. надав прохання на ім'я 
заступника головного інспектора інженерних військ (керівника інженерної оборони Севастополя під час Кримської війни), генерала Е. Тотлебена про виділення коштів. Однак Е. Тотлебен не підтримав цю ідею, оскільки вважав справу підводного плавання надто небезпечною i висловив сумнів щодо можливості підготовки відповідних фахівців для плавання на підводних човнах, а проєкт підводного човна О. Герна визнав недосконалим і прохання не задовольнив $[13$, с. $99 ; 17$, с. 58].

Загалом, хоча розробки О. Герна і поступалися тогочасним зарубіжним проєктам, він зробив вагомий внесок у вітчизняне підводне суднобудування, першим розділивши човен на водонепроникні відсіки, що підвищувало його живучість; використав гребний гвинт; першим здійснив спробу застосувати силову установку, здатну працювати за комбінованим циклом, та винайшов комплексну систему регенерації повітря та пневматичну торпеду власної конструкції.

Перший у Росії підводний човен із механічним двигуном вдалося сконструювати i побудувати талановитому інженеру Івану Александровському (1817-1894 рр.). Всебічно обдарована людина, він проявив себе як непересічний винахідник із креативним підходом, зокрема у справі конструювання i будівництва підводних човнів [17, с. 44]. Ураховуючи досвід попередників у справі конструювання субмарин, I. Александровський за сприяння відомого інженера-кораблебудівника Степана Бурачека (1800-1876 рр.), який виконав деякі розрахунки та запропонував зміни до проєкту (паровий двигун i водометний рушій [5, с. 130-131]), розробив свій перший проєкт човна. Для забезпечення його руху були встановлені дві пневматичні машини на два вали, для роботи яких стиснуте повітря запасалося у балонах під тиском 60-100 атм., чого мало вистачити на 20-30 миль плавання. Відпрацьоване повітря частково надходило всередину корпуса для дихання людей, надлишок - стравлювався за борт [14, с. 53; 17, с. 36] (подібно проєкту М. Спірідонова). 
Через три роки після проведених випробувань човна МТК визнав ідею I. Александровського “відважною” та “патріотичною” [17, с. 57]. Під час його відвідування 14 вересня 1866 р. та огляду зсередини імператор Олександр II визнав, що “все чрезвычайно умно придумано” і човен був включений до складу флоту. Найвищим наказом по Морському відомству I. Александровський був нагороджений орденом Володимира 4-го ступеню i зарахований на службу “вільним механіком” у чині титулярного радника (рівний морському чину лейтенанта) 3 річним жалуванням 5 тис. руб. і правом носіння мундира. У 1875 р. І. Александровський став уже надвірним радником, що відповідало чину капітана 2 рангу [13, с. 119].

Пізніше, у серпні 1876 р. винахідник запропонував установити на підводному човні парові котли на рідкому паливі, що вприскувалося б у топку за допомогою форсунок, а потім накопиченим паром продовжувати приводити в рух парову машину $[17$, с. 52$]$. Проте цю та подальші пропозиції щодо робіт з перебудови ПЧ, подані автором у 1878 та 1882 рр., МТК відхилив $[14$, с. $59-60 ; 17$, с. 51-52].

Незважаючи на цю невдачу, заслуги І. Александровського в історії розвитку підводного плавання беззаперечні [14, с.61], вони доповнені винаходом нової зброї - торпеди, проєкт якої інженер створив у 1865 р. $[14$, c. 63$]$, задовго до того, як англієць Уайтхед у 1876 р. оголосив про винайдену ним подібну зброю [13, с. 61].

Оригінальний проєкт субмарини розробив у 1869 p. відставний поручник О. Лазарєв. Крім інших започаткувань для цього типу корабля, конструктор планував втілити на ньому сміливу ідею “єдиного” двигуна для підводного і надводного ходу, причому спроєктував пристрій для подачі повітря до двигуна у підводному положенні - прообраз “шноркеля”. Проте, незважаючи на втілені прогресивні й оригінальні ідеї, вище керівництво визнало цей проєкт передчасним [17, с. 36-37].

Таким чином, численні патріотично налаштовані винахідники, незважаючи на невдачі, що переслідували їх на шляху до нових розробок, 
прагнучи сприяти захисту берегів від ворожого флоту, активно пропонували свої проєкти підводних човнів. Так, О. Герн першим у Росії спробував застосувати комбіновану силову установку; І. Александровський вирішив завдання побудови великого металевого підводного човна 3 механічним двигуном, причому уперше - двовального; О. Лазарєв розробив пристрій для роботи дизельного двигуна під водою, висловив ідею “єдиного” двигуна для підводного i надводного ходу, яку майже одночасно подав i німецький винахідник В. Бауер. Реальне втілення ідеї створення механічного двигуна для нового виду флотської зброї - підводного човна - було можливе тільки у результаті вирішення низки складних технічних проблем, що вимагало чимало часу. Але різні варіанти їх примітивного вирішення не призводили до елементарного задовільного виконання основних вимог до бойового підводного корабля. Відтак, спроби створення підводних човнів уподовж двох десятиліть 3 початку Кримської (Східної) війни 1853-1856 рр. були лише наполегливими, часом досить сміливими $\mathrm{i}$ дотепними пошуками вирішення важливих технічних проблем за умов відсутності коштів.

Після російсько-турецької війни 1877-1778 рр. питання розроблення та будівництва підводних човнів набуло особливої актуальності: протягом 1879-1880 рр. Морське міністерство розглянуло 5 проєктів [4, с. 37]. Саме на цей період припадає діяльність відомого вітчизняного інженера, уродженця Подільської губернії, Степана (Стефана Казимира) Джевецького (18431938 рр.) [2], з іменем якого пов’язано початок серійного будівництва перших субмарин у Росії [1, с. 3].

Активний учасник російсько-турецької війни, георгіївський кавалер [2; 11, с. 106] С. Джевецький послідовно спроєктував і побудував чотири підводних кораблі [4, с. 12]. Розпочавши із примітивних карликових субмарин із педальним приводом, протягом 1876-1883 рр. інженер розробив четвертий варіант ПЧ з акумулятором і електродвигуном потужністю 1,8 к.с. Один із човнів (50 од.) він пропонував оснастити гребним гвинтом, інший водометом. Отримавши схвалення начальства, С. Джевецький у 1884 р. сам 
спроєктував і виготовив потрібне йому електрообладнання [11, с. 108]. У 1885 р. на обох човнах було закінчено переобладнання і їх випробовували на Неві в Санкт-Петербурзі, при цьому човен із гребним гвинтом протягом 20 хв. йшов під водою проти течії річки зі швидкістю 4 вузли, водомет розвинув хід менше 3-х вузлів. Для управління по курсу конструктор замість поворотного гвинта запровадив вертикальне стерно. Однак у зв'язку 3 використанням старої зброї - зринаючих мін - МТК не визнав можливим прийняти цей човен на озброєння флоту [13, с. 132].

У 1887 p. С. Джевецький запропонував російському морському відомству проєкт підводного човна надводною водотоннажністю 55 т і підводною - 63 т, рух якого на поверхні мала забезпечити парова машина потужністю 300 к.с. (до 15 вуз.), що працювала на нафті, під водою електромотор потужністю 100 к.с. (до 10 вуз.), що працював від акумуляторної батареї з 400 елементів. Розрахункова дальність плавання повним ходом у надводному положенні передбачалася до 600 миль, під водою на електромоторі - 30 миль. Човен мав подвійний корпус (iз проміжком між обшивками у 20 см), і розрахований на глибину занурення до 20 м. Озброєння складали 2 рамкових торпедних апарати власної конструкції (боєкомплект 4 торпеди) [13, с. 156; 11, с. 108].

Після відхилення цього проєкту МТК С. Джевецький у 1892 p. переробив його і в 1896 р. представив на конкурс морського міністерства Франції, за який отримав 2-гу премію (1-шу - не вручали нікому). Він являв собою збільшений у габаритах і трохи змінений у деталях попередній корабель. Водотоннажність за проєктом становила 190 т, дві парові машини Лаваля на рідкому паливі мали забезпечити надводний хід 15 вуз. протягом 48 год. (720 миль). Розрахункова швидкість під водою на електромоторах планувалася у 10 вузлів. Озброєння човна складали 4 рамкових торпедних апарати по бортах субмарини авторського проєкту [11, с. 109].

Протягом 1903-1904 pp. на замовлення "Комітету з посилення флоту" на кошти, пожертвувані поштовими працівниками, С. Джевецький 
спроєктував свій черговий підводний човен, що у грудні 1904 р. був закладений на Металічному заводі у Санкт-Петербурзі, а в жовтні 1906 р. спущений на воду. Проте ходові випробування, розпочаті 28 вересня 1907 р., завершилися лише в серпні 1909 р. Із зарахуванням до бойового складу флоту 23 вересня 1909 р. човен і отримав свою назву “Почтовый” [1, с. 128].

П’ять моторів складали силовий блок човна: два бензинових по 130 к.с, що працювали на гребний вал; бензиновий у 60 к.с. - на компресор повітря високого тиску; бензиновий на 5 к.с. - на електрогенератор; пневматичний на 60 к.с. - на газовий насос. Повітря для роботи бензинових моторів надходило 3 машинного відділення, яке сполучалося 3 атмосферою через відкритий вхідний люк. Під водою працював тільки один гребний бензиновий мотор, при цьому повітря він отримував від батареї із 45 повітряних балонів загальним об’ємом $10 \mathrm{~m}^{3}$. Човен водотоннажністю $134 / 148$ т на випробуваннях досягнув максимальної швидкості у 11,4 вуз. у надводному та 6,1 вуз. у підводному положенні; розрахункова дальність плавання визначалася 340 та 27 миль відповідно; глибина занурення - 30 метрів. Озброєння складали 4 рамкових торпедні апарати для 457-мм торпед, екіпаж налічував 11 осіб [13, с. 128].

Крім того, на човен передбачалася установка мотора єдиного ходу, що мав працювати по замкнутому циклу [13, с. 129] (проєкт мічмана М. Нікольського (1888-1969рр.), помічника командира ПЧ “Почтовый”) (12.09.1912-28.09.1913). Оригінальність установки полягала у використанні кисню замість стиснутого повітря і винесення процесу очищення вихлопних газів та збагачення їх окислювачем із двигуна у самостійну систему регенерації. Побудовану модель двигуна, що працював на суміші кисню із вихлопними газами, М. Нікольський представив комісії Морського відомства у 1912 р. [5, с. 584]. Однак ідея не отримала подальшого розроблення і човен, простоявши на береговій стінці заводу одинадцять років, у вересні 1924 р. розібрали на метал [13, с. 129]. 
Таким чином, упродовж 1877-1908 pр. С. Джевецький спроєктував 11 підводних човнів, більша частина 3 яких була побудована і випробувана, причому проєкт 1885 р. мав електромотор у якості двигуна, що живився від акумуляторної батареї; проєкти 1887 та 1892 рр. для надводного ходу використовували парові машини на нафті, для підводного - електромотори, а ПЧ “Почтовый” 1909 р. побудови мав комбіновану машину з бензиновими, електричними та пневматичним двигунами та мотором єдиного ходу замкнутого циклу.

У період російсько-японської війни 1904-1905 pp. із розвитком технічної думки проєктуються підводні човни, що в якості рушіїв мали двигуни внутрішнього згорання. Одним із перших такого типу став підводний човен “Кета" лейтенанта Сергія Яновича (1878-1935рр.). Із початком російсько-японської війни у 1904 р. один із законсервованих човнів С. Джевецького третьої серії модернізували, встановивши на ньому бензиновоий двигун замість велосипедного приводу і два рамкових апарати системи Джевецького для торпед калібру 381 мм. Човен міг плавати тільки в напівпідводному положенні (нині його називають позиційним або крейсерським). При цьому повітря для забезпечення роботи двигуна засмоктувалося через спеціальну трубу, свого роду примітивний “шноркель” [13, с. 125]. Таким чином, Янович фактично повторив ідеї попередників Герна та зарубіжних конструкторів Барбура і Холланда [10, с. 39].

Після випробувань і усунення виявлених недоліків комісія, яку очолював відомий вчений-кораблебудівник О. Крилов (1863-1945рp.), прийняла цей човен. У 1905 р. його зарахували до складу російського флоту під назвою “катер малої видимості “Кета” і у травні доправили залізницею на Далекий Схід, де під командуванням С. Яновича його зарахували до складу Загону оборони гирла Амура з базуванням у Ніколаєвськ-на-Амурі [8, с. 108; 13, с. 125]. У період із 3 червня по 20 вересня того ж року він здійснив 17 виходів у море, пройшовши майже 950 миль [13, с. 126]. Наявність у гирлі Амуру субмарини здійснювала стримуючу дію на противника і змусила його 
відмовитися від планів висадити десант у даному районі. Утім, незважаючи на спроби модернізації, цей тип човна - напівзануреного - вже був застарілим [10, с. 40].

У 1904 р. на Балтійському заводі у Санкт-Петербурзі на базі одного із серійних човнів С. Джевецького за проєктом лейтенанта російського флоту О. Боткіна був перероблений човен “Чилимъ” водотоннажністю 14 т, що також міг плавати у двох положеннях: надводному і позиційному. Двигуном єдиного ходу служив один гасовий мотор потужністю 1 к.с., повітря для його роботи при плаванні в позиційному положенні також засмоктувалося через спеціальну трубу [6, с. 138]. Озброєння складали 2 рамкові торпедні апарати С. Джевецького для 381-мм торпед. 17 серпня 1904 р. на рейді Кронштадта було проведено успішне випробування торпедних апаратів, проте човен продемонстрував занадто низьку швидкість для активних дій, що змушувало доправляти його до району дій тільки на буксирі. Утім, за відсутності вибору після повернення на буксирі назад до Санкт-Петербурга човен завантажили на залізничну платформу і відправили до Владивостока. Однак через низькі технічні характеристики (навіть гіршими, ніж у “Кети”) у бойових діях проти японців його не застосовували [13, с. 127].

Улітку 1904 р. в обложеному японцями Порт-Артурі залізничний технік Михайло Нальотов (1869-1935 рр.) побудував ПЧ водотоннажністю 25 т. За наявними відомостями, за своєю будовою він був подібний до “Кети” i “Чилима", тобто був напівпідводним судном без електромотора для руху на глибині. М. Нальотов планував, що його озброєння буде складатися із 2-х торпед Уайтхеда в рамкових апаратах зовні корпуса або 3 4-х якірних мін загородження. За результатами проведених восени випробувань і пробного занурення на 10 м було вирішено встановити на човні гасовий мотор із роз’їзного катера броненосця “Пересветь” [6, с. 137]. Проте із капітуляцією фортеці, бажаючи зберегти свій винахід у таємниці, 20 грудня (за старим стилем) М. Нальотов підірвав підводний човен на внутрішньому рейді гавані [13, c. 127]. 
Ще у 1834 p. німецький фізик i електротехнік Моріц Герман (3 прийняттям російського підданства - Борис Семенович Якобі (1801-1874 pp.) винайшов електромотор. У Санкт-Петербурзі професор Якобі застосував свій двигун для обертання гребного колеса, встановивши його на невеликому баркасі, і 13 вересня 1838 р. продемонстрував тригодинне плавання по Неві на очах у численних глядачів. Перший у світі судновий електромотор живився від гальванічної батареї, що складалася з 320 мідних і цинкових елементів округлої форми. Значення електромотора для підводного плавання відразу ж оцінив інший видатний військовий інженер генерал Карл Шільдер [15, арк. 293]. Проте електромагнітний двигун, над проблемою створення якого працював Б. Якобі, був винайдений дещо пізніше, у другій половині XIX ст. [9, с. 139]. Таким чином, використання потужних електромоторів на підводних човнах стало можливим лише після винайдення акумуляторів, здатних зберігати великі запаси електроенергії. Лише у 1884 р. французький учений К. Фор запатентував акумулятор із гратчастими свинцевими пластинами, розділеними пергаментними прокладками, зібраними в пакети i залитих розчином сірчаної кислоти. Акумулятори такого типу мали значну ємність і з часом набули широкого розповсюдження [13, с. 127]. Саме їх впровадження забезпечило можливість тривалого плавання у морських глибинах.

У 1885 p. С. Джевецький першим у вітчизняному підводному кораблебудуванні використав електродвигун, який для обертання гвинта живився струмом від акумуляторної батареї, на четвертому варіанті (переробленому з третього, серійного) човна [13, с. 132]. До слова, цей човен зберігся до наших днів і представлений в експозиції Центрального військовоморського музею в Санкт-Петербурзі.

У 1901 р. за проєктом лейтенанта Свгена Колбасьєва (1862-1918 рр.) у майстернях Кронштадтського порту корабельний інженер Микола Кутейников (1872-1921рp.) побудував човен із розбірним корпусом, названий "Петр Кошка" [8, с. 110]. Головною відмінністю цього човна стала 
наявність шести електромоторів загальною потужністю 24 к.с., гребні вали яких були розташовані під кутом 20 градусів до діаметральної лінії корпуса. Ці шість двигунів давали змогу розвивати максимальну швидкість 8,5 вузлів (15,74 км/год) на поверхні і 6 вузлів (11,1 км/год) під водою. Акумулятори загальною масою 4 т забезпечували 15-мильну дальність плавання під водою на швидкості 3,5 вуз. або 40 миль в надводному положенні на 4 вуз. Проте замість високої маневреності, як сподівалися автори проєкту, човен вийшов надзвичайно нестійким у русі: незначна зміна числа обертів будь-якого із шести електромоторів викликала відхилення від заданого курсу [1; 3 с. 150]. Тому даний проєкт не отримав подальшого розвитку, i у лютому 1904 р. човен відправили у Порт-Артур, де він простояв у порту до кінця оборони. Напередодні капітуляції фортеці, наприкінці грудня 1904 р. човен затопили у західній частині гавані [8, с. $110 ; 13$, с. 152].

Однією 3 перших сконструйованих i збудованих субмарин iз електричним ходом став човен-електрохід “Форель” (“Forelle”) у 1903 р. Човен, сконструйований іспанським інженером Раймондо д’Еквілем, у 1904 р. фірма Фрідріха Круппа подарувала російському Морському міністерству у якості дослідного за три замовлених ПЧ типу “Карпъ” [6, с. 133]. Електромотор потужністю 60 л.с. забезпечував повний хід до 8 вуз. на поверхні (дальність плавання 20 миль на 4,5 вуз.) і близько 6 вуз. під водою (дальність плавання під водою - 18 миль на 3,5 вуз.). Озброєння складалося з двох 457-мм торпед у трубних апаратах зовні корпуса побортно $[14$, c. 135$]$.

Після проведених у Санкт-Петербурзі випробувань із початком російсько-японської війни човен доправили залізницею 3 Лібави до Владивостока, де під командуванням лейтенанта Тимофія Фон-дер РаабТіллена (1880-1929) [5, с. 674] “Форель” протягом п’яти місяців був єдиною формально діючою підводною одиницею флоту на Тихоокеанському театрі, хоча у море він не виходив, перебуваючи у стані готовності до закінчення війни [7, с. 6]. 
Першою повноцінною бойовою одиницею став збудований у 1903 р. за проєктом І. Бубнова та М. Беклємішева підводний човен “Дельфинь”, на якому встановили бензиновий двигун заводу Даймлера (Німеччина) за проєктом інженера Луцького [6, с. 130] та електродвигун підводного ходу $[12$, c. 136].

Утім, наявність на човнах пожежонебезпечних бензинових та гасових (газолінових) двигунів внутрішнього згоряння потребувало розроблення та встановлення більш досконалого i безпечного двигуна внутрішнього згоряння для надводного ходу, яким і став дизельний двигун, освоєний на вітчизняних підприємствах і встановлений восени 1905 р. на підводному човні нового типу “Минога” [17, с. 78$]$.

Отже, пройшовши еволюцію від використання м'язової сили та застосування повітряних (пневматичних) машин для руху у надводному та підводному положеннях, з розвитком техніки наприкінці XIX - на початку XX ст., зокрема електричних акумуляторів та електромоторів, вдалося частково вирішити проблему двигуна для підводного човна.

Після багаторічних досліджень і дослідів на початку XX ст. загальне визнання отримала подвійна система двигунів для субмарин: для руху на поверхні води бензиновий або газоліновий двигун, а під водою електромотор, який живиться від акумулятора. Наступним прогресивним кроком стало створення та використання на підводних човнах для надводного ходу дизельного двигуна.

Вдале вирішення цієї проблеми, як і інших, зокрема широкий розвиток оптики, що дала перископ, і вдосконалення торпедної зброї зумовило значний стрибок у розвитку підводних човнів, що у подальшому повною мірою продемонстрували свої якості і здобули право на рівне, а потім і на перше місце серед інших класів бойових кораблів у боротьбі на морських комунікаціях противника та при виконанні інших численних завдань як у відкритому морі, так і в прибережних районах. 


\section{Список використаних джерел і літератури}

1. Александров Ю.И. Отечественные подводные лодки до 1918 года (Справочник). - Бастион. - Военно-технический сборник. - 2002. - Выпуск 6. $-75 \mathrm{c}$.

2. Крючков Ю. Джевецкий Стефан Казимирович. Изобретатель первой русской боевой подводной лодки: [Электрон. ресурс]. - Режим доступа: http://odesskiy.com/d/dzhevetskij-stefan-kazimirovich.html.

3. Морской сборник. - 1857. - №2.

4. Платонов А.В. Подводные лодки. - СПб. : ООО “Изд-во "Полигон”, 2002. $-256 \mathrm{c}$.

5. Пожарський А.М. Подводное плавание в России. 1834-1918. - СПб. : “Русско-Балтийский информационный центр “Блиц”, 2011. - 1024 с.

6. Соколюк C.M. Будівництво та нарощування підводних сил російського флоту на Тихоокеанському театрі воєнних дій під час російськояпонської війни (1904-1905рp.) / С.М.Соколюк // Воєнно-історичний вісник. - 2017. - Вип. 1 (23). - С. 130-139.

7. Соколюк С.М. Досвід перевезення підводних човнів на Далекий Схід під час російсько-японської війни (1904-1905 рр.) / С. М. Соколюк // Досвід застосування збройних сил у світових війнах і воєнних конфліктах XX початку XXI ст.: тенденції та закономірності : зб. наук. праць / Кол. авторів. За ред. С.В. Сидорова. - К. : ЦП “Компринт”, 2017. - Вип. 6. - 159 с. - С. 4-9.

8. Соколюк С.М. Застосування підводних човнів на Тихоокеанському театрі воєнних дій під час російсько-японської війни (1904-1905рр.) (продовження) / С. М. Соколюк // Воєнно-історичний вісник. - 2018. - Вип. 3 (29). - C. 106-116.

9. Соколюк С.М. Розвиток вітчизняного підводного кораблебудування в першій половині XIX ст. / С. М. Соколюк // Воєнно-історичний вісник. 2014. - № 2 (12). - C. 136-143.

10. Соколюк С.М. Розвиток двигунів для підводних човнів російського флоту наприкінці XIX - на початку XX століття // Підводна техніка і 
технологія : матеріали VIII Всеукраїнської науково-технічної конференції 3 міжнародною участю : в 2 ч. - Миколаїв : НУК. - 2018. - Ч. 1. - С. 35-43.

11. Соколюк С.M. Розвиток підводного кораблебудування в Україні в останній чверті XIX ст. / С. М. Соколюк // Воєнно-історичний вісник. - 2015. - Вип. 1 (15). - С. 105-110.

12. Соколюк C.M. Розвиток підводного кораблебудування у Росії (19001904 рр.) / С. М. Соколюк // Воєнно-історичний вісник. - 2016. - Вип. 4 (22). - C. 134-140.

13. Тарас A.E. История подводных лодок 1624-1904. - М. : АСТ; Мн. : Харвест, 2002. - 240 с.

14. Трусов Г.М. Подводные лодки в русском и советском флоте. - Л. : Госсудпром, 1957. - 381 с.

15. Центральный военно-исторический архив (далее - ЦВИА), ф. 1, оп. 1, д. 44.

16. ЦВИА, ф. 402, оп. 3, спр. 60.

17. Шерр С.А. Корабли морских глубин. Изд. 3-е. - М. : Воениздат, 1964. $-328 \mathrm{c}$.

Sokoliuk S.M., Candidate of Historical Sciences, Associate Professor, Associate Professor of Navy Department of Ivan Cherniakhovskyi National Defense University of Ukraine (Kyiv)

\section{CREATION OF SUBMARINE ENGINES ON THE DOMESTIC TERRITORY (THE SECOND HALF OF THE XIX - THE BEGINNING OF THE XX CENTURY)}

The article revealed the process of development of engineering decisions on creation of engines for submarines in the second half of XIX - beginning of $X X$ century. The activities of local inventors on the solution of the problem of engine development that would ensure the movement of the submarine, as a special class of combat ships, in surface and underwater position, are reflected. Having started from the pedal and manual drive for the submarines movement, the 